\title{
Література:
}

1. Гайдук Л. М., Васильєва І.В. Сучасні технології моделювання і художнього оздоблення одягу: навч. посіб. Київ : КНУТД, 2008. 142 с.

2. Абилкамова К. К. Разработка методики формирования многофункционального гардероба женской одежды на основе инновационных технологий : дис. ... д-ра философии : 6D072600. / Алматинский технологический университет. Республика Казахстан, Алматы, 2018. $145 \mathrm{c}$.

3. Васильєва О. С, Колосніченко О. В., Васильєва І. В., Остапенко Н. В. Розробка класифікації видів і принципів реалізації функції трансформації дитячого шкільного одягу і гардеробу. Теорія $i$ практика дизайну: Збірник наукових праць. Технічна естетика. Київ, «Дія», 2017. Вип. 13. С. 27-41.

4. Остапенко Н. В. Розвиток наукових основ дизайн-проектування захисного одягу з використанням принципу трансформації : дис. ... д-ра техн. наук : 05.18.19. / Київський національний ун-т технологій та дизайну. Київ, 2017. 367 с.

DOI https://doi.org/10.30525/978-9934-26-004-9-101

\section{ШРИФТ ЯК ЕЛЕМЕНТ ДИЗАЙНУ ВЕБ-САЙТА КОМЕРЦІЙНОГО ПІДПРИЕМСТВА}

\author{
Васильєв О. С. \\ аспірант кафедри ергономіки і дизайну \\ Київського національного університету технологій і дизайну \\ Колосніченко О. В. \\ доктор мистеитвознавства, професор, \\ професор кафедри художнього моделювання костюма \\ Киїського національного університету технологій $і$ дизайну \\ Васильєва I. В. \\ дочент кафедри ергономіки і дизайну \\ Київського національного університету технологій і дизайну \\ м. Київ, Украӥна
}

Сучасний бізнес неможливо уявити без новітніх технологій та глобальної комп'ютерної мережі Інтернет. Інтернет-торгівля - це сучасний та відносно дешевий канал продажів, що слугує ефективним доповненням традиційної торгівлі, а в деяких випадках і самостійним 122 
суб'єктом торгівлі. Серед малого та середнього бізнесу сьогодні Інтернет стає вкрай привабливим інструментом, через те, що має переваги перед іншими засобами торгівлі, серед яких: вибірковий вплив на цільову аудиторію, висока якість контакту, інтерактивність, низька вартість тощо. Все це призводить до формування категорії електронного підприємництва, де якість веб-сайту стає важливою умовою розвитку електронного бізнесу [1].

Мета будь-якого комерційного сайту отримання максимального числа зацікавлених відвідувачів і перетворення їх в клієнтів. Відвідувач, приходячи на сайт інтернет-магазину з різними цілями, бачить його дизайн і контент, а також взаємодіє з інтерфейсом. Якщо йому щось не подобається, він закриває вікно браузера або йде на інший сайт. Тому специфіка розробки сайтів дуже тісно пов'язана 3 таким поняттям як юзабіліті, яке можна визначити як зручність використання сайту відвідувачем. До юзабіліті відноситься створення зручної і зрозумілої навігації, приємних оку шрифтів на сторінці, колірної гами, що не дратує, а також наявність корисної інформації, поданої в прийнятному, легкому для читання вигляді. Всі елементи дизайну сайту грають важливу роль в процесі конверсії відвідувача сайту в клієнта. Кожен 3 них має певне значення для створення якісного веб-сайту. Одним 3 найбільш важливих елементів дизайну сайту є правильний вибір шрифту для викладу текстової інформації [2].

Шрифт веб-сайту виконує інформативну функцію, бо $є$ носієм інформації, і може виступати елементом концентрації уваги користувача сайту. Як елемент дизайну шрифти сайту повинні складати єдине ціле 3 його дизайном і за розміром, і за гарнітурою, і за кольором. Текстові блоки на сайті повинні відповідати основним вимогам до зручності читання, бути цільними і комфортними для сприйняття користувачем. Саме від шрифту як носія інформації залежить комфортність читання матеріалів сайту і втомлюваність користувача. Читаність шрифту, в свою чергу, багато в чому визначається розміром шрифту, його гарнітурою, кольором фону, кольором тексту, наявністю допоміжної графіки, розміром текстової колонки і полів, відстанню між рядками та між символами. Розглянемо особливості для сайтів інтернет-магазинів більш докладно.

При публікації контенту в мережі Інтернет дотримуються правил типографіки, які дозволяють отримувати позитивні емоції при читанні, привернути і зацікавити клієнта, правильно розставляти локальні акценти і паузи в відповідних за змістом місцях, легко запам'ятовувати головні думки тексту, прояснювати його структуру і послідовність, викликати необхідні емоції від наданого матеріалу [3]. 
Основою сучасної типографічної картини Всесвітньої мережі Інтернет стали «web-safe fonts» - шрифти, що присутні в домінуючих на ринку операційних системах. Їх небагато - приблизно двадцять. Найчастіше на сайтах інтернет-магазинів зустрічаються такі шрифти, як Verdana, Arial, Times New Roman i Courier New. Протягом багатьох років їх склад зберігається, незважаючи на те, що «канон» таких шрифтів частково розширюється їх варіантами та копіями [4].

При написанні тексту для сайту враховують два основні правила: тексти повинні бути короткими; тексти повинні бути структуровані за правилом «піраміди»: від основних тез - до обгрунтування і більш докладного розгляду теми. Найцікавішу і корисну частину інформації, як правило, розташовують у верхній частині тематичної області, і вона $\epsilon$ доступною без прокрутки сторінки [5].

Розмір основного шрифту повинен залежати від аудиторії сайту. Для дітей і людей похилого використовують шрифти більшого розміру, для інших цільових аудиторій - більш дрібні. Найзручнішою для читання $\epsilon$ гарнітура «Verdana». Часто застосовуються такі прості і строгі гарнітури «без зарубок», як «Arial», «Courier», «Tahoma» i «Georgia», а для заголовків - шрифти «із зарубками» (Georgia, Times New Roman). При підборі шрифтів найкраще користуватися відносними величинами (відсотками) такий текст легше масштабувати. Інформацію найчастіше подають друкованими літерами, бо так вона сприймається легше. При використанні великої кількості тексту написаного прописними буквами знижується швидкість читання і погіршується сприйняття його змісту $[2,5]$.

При розробці веб-сайту і всього дизайну велику увагу приділяють не лише вибору самого штифта, але і його кольору і кольору фону, на якому шрифт буде розташовуватися. Для сайту інтернет-магазину часто вибирають більш темні кольори для відображення шрифту і світлі - для фону. Кольори шрифту i фону часто роблять контрастними по відношенню один до одного. При цьому колірні співвідношення не повинні дратувати. У цьому випадку клієнтові буде комфортно сприймати текстові елементи. В іншому випадку читабельність тексту значно знижується. Для забезпечення комфорту клієнта часто для фону використовують світлі відтінки сірого, зеленого, блакитного тощо. Ці природні кольори і їх світлі відтінки сприяють концентрації уваги і не напружують зір людини. Наприклад, комфортно сприймається шрифт темно-синього або чорного кольору на світло-сірому фоні. Кращий варіант для сайту - чорний текст на білому фоні.

Правильно підібраний шрифт повинен гармоніювати 3 іншими візуальними елементами сайту. При використанні на сайті декількох шрифтів 3 різним накресленням часто виникає дисгармонія в текстовій 
частині. Тому на одному сайті використовують не більше трьох різних шрифтів одночасно.

Для залучення користувачів і концентрації їх уваги заголовки на вебсторінці, на відміну від інших текстових блоків, часто роблять яскравими і контрастними. Якщо в тексті є візуально виділені об'єкти, то клієнт звертає свою увагу в першу чергу саме на них, а зацікавившись переходить до вивчення всього тексту. Інформацію в тексті виділяють за рахунок розміру i кольору шрифту, різного написання шрифту, підкреслення, великих і малих літер тощо. При цьому на сайті інтернетмагазину, як правило, не використовують більше чотирьох різних кольорів тексту. Також застосовують яскраві підкладки під текст в якості заднього фону у випадках, коли хочуть залучити й акцентувати увагу користувача на значущих частинах інформації.

Важливим показником для комфортності читання $\epsilon$ ширина рядка тексту. Ідеальна рядок складається з 50-70 знаків [6]. У всіх інших випадках швидкість читання сповільнюється, а стомлюваність підвищується. Для утримання погляду на текстовій колонці сторінки та усунення мимовільних переводів погляду на сусідні колонки розмір полів повинен бути не менше $10 \%$ від ширини текстового рядка, практично достатньо близько 7-10 символів [6]. Занадто малі відстані між символами та рядками також значно знижують комфортність сприйняття інформації.

Шрифт служить продовженням корпоративного стилю компанії і $\epsilon$ елементом цього стилю. Якщо інтернет-магазин має фірмові шрифти, то їx, як правило, використовують на його сайті хоча 6 в заголовках [6]. Цим також досягають стильової єдності в оформленні всіх візуальних елементів компанії як в поліграфічній продукції, так і веб-сайті. Таким чином, правильний вибір шрифтів, як елемент дизайну сайту, сприяє його кращому сприйняттю, його ефективної роботі, збільшенню конверсії відвідувачів сайту в клієнтів і успішності бізнесу в цілому.

\section{Література:}

1. Комарницький I. М., Бублик М. І., Мужилівський М. Д. Розробка концепції оцінки якості веб-сайтів як умови розвитку електронного підприємства. Вісник Житомирського державного технічного університету. Житомир, 2008. № 1 (43). Економічні науки. С. 177-189.

2. Якутова О. М., Петрова О. А. Шрифт как элемент дизайна вебсайта. Актуальные проблемы авиации $u$ космонавтики. Фундаментальные и прикладные проблемы гуманитарных наук. Красноярск, 2013. C. 243-274 
3. Петрова В. В., Калугина Д. А. Применение типографики для подготовки контента. Весник Московский государственный университет печати имени Ивапа Федорова. Москва, 2015. № 5. С. 19-21.

4. Беляев А. А. Актуальные проблемы современной вебтипографики: взгляд в будущее. Весник Московского ун-та. Сер. 10. Журналистика. Москва, 2010. № 3. С. 15-22.

5. Дизайн сайта и юзабилити: практический аспект. URL: https://griban.ru/blog/46-dizajn-sajta-i-juzabiliti-prakticheskij-aspekt.html (дата звернення: 15.11.2020).

6. Шрифты (фонты) корпоративного сайта. URL. http.//www.corpsite.ru/Encyclopedia/CreateSite/Design/Type.aspx (дата звернення: 17.11.2020).

DOI https://doi.org/10.30525/978-9934-26-004-9-102

\title{
ОСОБЛИВОСТІ РОЗРОБКИ КОЛЕКЦІЙ ДИТЯЧОГО ОДЯГУ ЗА ПРИНЦИПАМИ ЕКО-ДИЗАЙНУ
}

\author{
Векліч А. М. \\ аспірант факультету дизайну \\ Макалістер Т. O. \\ магістр факультету дизайну \\ Процик Б. О. \\ магістр факультету дизайну
}

Колосніченко О. В.

доктор мистеитвознавства, професор, професор кафедри художнього моделювання костюму

Пашкевич К. Л.

доктор технічних наук, професор,

професор кафедри ергономіки і дизайну

Київського начіонального університету технологій та дизайну м. Київ, Україна

Проблема забруднення навколишнього середовища в сучасному світі стоїть дуже гостро, зокрема одним із джерел негативного впливу є легка промисловість і таке явище як «швидка мода» (від англ. fast fashion). Ïї суть полягає у зміні асортименту одягу брендів по кілька разів протягом сезону, що перенасичує ринок товарами, знижуючи практичну 